\title{
EFFECT OF PASTURE VERSUS CONVENTIONAL FEEDING SYSTEMS ON THE COMPOSITION OF MILK PRODUCED IN PORTUGAL
}

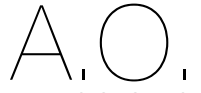

ARTIGO ORIGINAL

${ }^{1}$ Centro de Engenharia

Biológica da Universidade do Minho,

Campus de Gualtar,

4710-057 Braga, Portugal

"Endereço para correspondência:

José A Teixeira

Centro de Engenharia Biológica

da Universidade do Minho,

Campus de Gualtar,

4710-057 Braga, Portuga

jateixeira@deb.uminho.pt

Histórico do artigo:

Recebido a 2 de setembro de 2020 Aceite 331 de dezembro de 2020

\author{
EFEITO DA PASTAGEM VERSUS SISTEMAS DE ALIMENTAÇÃO \\ CONVENCIONAIS NA COMPOSIÇÃO DE LEITES PRODUZIDOS \\ EM PORTUGAL
}

\section{ABSTRACT}

INTRODUCTION: Cows' milk is widely consumed and is considered essential for the diet of billions of people worldwide. Conjugated linoleic acid and omega-6/omega-3 ( $\omega 6 / \omega 3)$ ratio have been associated with the improvement of human health. The feed factors of cows are highly related with the lipidic composition of milk.

OBJECTIVES: Compare the effect of the two different feeding systems (pasture and conventional) in conjugated linoleic acid concentration and in $\omega 6 / \omega 3$ ratio in milk produced in Portugal.

METHODOLOGY: The study includes the data analysis of the provided reports, containing the results of the 12 samples (2018-2020) from 3 different brands (Portugal), and their graphical comparison.

RESULTS: The concentration of conjugated linoleic acid is always higher (around $10 \mathrm{mg} / 100 \mathrm{~g}$ of conjugated linoleic acid) in milk $\mathrm{A}$ (pasture milk) and presents a more constant profile throughout the sampling period. Also, the $\omega 6 / \omega 3$ ratio of pasture milk presents a more constant profile and the ratio values are the closest to the recommended.

CONCLUSIONS: The pasture-feeding system produces milk more nutritionally enriched, with a composition more constant through the different seasons of the year and ensuring the welfare of cows. The milk produced by those systems appears to have an improved fatty acids profiling.

\section{KEYWORDS}

Conjugated linoleic acid, Omega-6/omega-3 ratio, Pasture milk, Pasture-feeding system

RESUMO

INTRODUÇ̃̃o: O leite de vaca é amplamente consumido e considerado essencial para a dieta de milhares de milhões de pessoas em todo o mundo. A concentração de ácido linoléico conjugado e o rácio ómega-6/ómega-3 (w6/w3) têm sido associados à melhoria da saúde humana. Os fatores alimentares das vacas estão altamente relacionados com a composição lipídica do leite. OBJETIVOS: Comparar o efeito dos dois diferentes sistemas de alimentação (pastagem e convencional) na concentração de ácido linoléico conjugado e no rácio $\omega 6 / \omega 3$ em leites produzidos em Portugal.

METODOLOGIA: O estudo inclui a análise dos dados dos relatórios fornecidos, contendo os resultados das 12 amostras recolhidas (2018-2020) de 3 marcas diferentes (Portugal), e sua comparação gráfica.

RESULTADOS: A concentração de ácido linoléico conjugado é sempre superior (em torno de $10 \mathrm{mg} / 100 \mathrm{~g}$ de ácido linoléico conjugado) no leite A (leite de pastagem) e apresenta um perfil mais constante ao longo do período de amostragem. Além disso, o rácio w6/w3 do leite de pastagem apresenta um perfil mais constante e valores da razão mais próximos aos recomendados.

CONCLUSÕES: O sistema de alimentação de pastagem produz leite mais enriquecido nutricionalmente, com uma composição mais constante nas diferentes estações do ano, e garante o bem-estar das vacas. O leite produzido por estes sistemas parece apresentar uma melhoria no perfil de ácidos gordos.

PALAVRAS-CHAVE

Ácido linoléico conjugado, Rácio ómega-6/ómega-3, Leite de pastagem, Sistema de alimentação de pastagem

\section{INTRODUCTION}

Milk is considered a drink of choice, widely consumed and essential for the diet of billions of people worldwide. In addition to its primary role, feeding newborns, milk is consumed by individuals of all age groups, due not only to its pleasant sensory characteristics, but also for the purpose of improving well-being and health in general (1). Cow's milk is the leader in the global milk production representing $83 \%$ of the total milk production (2). Milk is considered an important source of nutrients, with protein, minerals, fats, carbohydrates and vitamins in its composition. For this reason, cow's milk is considered a high-quality food for human nutrition (3).

Excluding water, fat represents one of the main components of cow's milk, having as main functions to serve as a source of energy and to be a source of essential fatty acids 
$(3,4)$. About $98 \%$ of the fat fraction of milk consists of triacylglycerols (TAG), while lipids such as diacylglycerols, cholesterol, phospholipids and free fatty acids can also be found in much lower percentages (below 2\%) (5-7). Triacylglycerols can be structurally classified into two distinct groups, the saturated ones, which represent a total of $70 \%$, and the unsaturated ones, which complete the remaining 30\%. Unsaturated fatty acids are further subdivided into monounsaturated and polyunsaturated, including the vaccenic acid, omega-3 (w3), omega-6 ( $\omega 6$ ) and the conjugated linoleic acid (CLA) (3).

The presence of unsaturated fatty acids in human diet has been associated with benefits in human health. Specifically, CLA has been found to have hypocholesterolemic and anti-atherogenic properties, an immunostimulant effect and an antioxidant role (8-12).

Also, the $\omega 3$ and $\omega 6$ influence human health in many ways. The deficiency of some $\omega 3$ and $\omega 6$ can affect memory, learning and vision. Moreover, some have positive effects on cardiovascular and neurodegenerative diseases and have shown to have anti-inflammatory properties (13). With the current dietary practices, the optimal $\omega 6 / \omega 3$ ratio is $4: 1(14,15)$.

The fatty acid composition of cow's milk is influenced by animal factors (breed, genetics, lactation status) and feed factors (diet and farm management practice) (11,16-18).

Scientific studies demonstrate that milk fat is very sensitive to the diet that cows are subjected to. Animals that eat fresh grass in greater quantity produce milk with a lipidic profile more beneficial to human health, particularly concerning the increased concentrations of some hypocholesterolemic unsaturated fatty acids (19). It has been proved that animals that have access to fresh forage in larger quantities produce milk with a lower $\omega 6 / \omega 3$ ratio and it is therefore closer to the recommended $(20,21)$.

Also, milk from pasture-based feeding systems can contribute to controlling environmental problems such as gas emissions and the contamination of aquatic environments since an suitable diet allows the reduction of methane emissions and mitigates the environmental pollution of nitrogen by the production of cow's milk (22).

This feeding system also allows animals to remain freely in their natural habitat, the pastures, instead of being enclosed in small compartments, feeding on rations, such as in conventional intensive feeding systems (23). Even if carried out only during part of the day, the pasture is a more sustainable practice, has a positive effect on the health of animals, can reduce environmental damage, improve the nutritional quality of milk and also contributes to improve human health $(23,24)$.

Thus, the development of studies that contribute to a global database that allows distinguishing the different milks from different regions/ countries is of great relevance because it will allow to identify the main differences between the milks and the main factors that influence the composition of cow's milk allowing the development of more controlled and improved milk production.

\section{OBJECTIVES}

The main objective of this work is to compare the effect of two different feeding systems, pasture-feeding systems and conventional-feeding systems (intensive indoor), on the lipidic profile of cow's milk produced in Portugal, namely in terms of the concentration of CLA and the w6/ $\omega 3$ ratio. Additionally, this work aimed to evaluate the variation of these parameters through the sampling period.

\section{METHODOLOGY}

In order to determine whether pasture milk (A) has better properties than milk obtained through conventional systems $(B, C)$ throughout the year, specifically regarding the CLA concentration and the $\omega 6 / \omega 3$ ratio, 12 milk samples from each brand of semi-skimmed UHT milk produced in Portugal were collected by GO LIVE!, Portugal between 2018 and 2020 in different days, englobing the different seasons. The samples were previously analyzed by SILLIKER PORTUGAL, S.A., Portugal. The CLA, $\omega 6, \omega 3$ and $\omega 6 / \omega 3$ ratio were determined according to ISO 15885:02.

The CLA concentration and $\omega 6 / \omega 3$ ratio values obtained are presented with the means of the 12 samples and respective standard deviations. One-way ANOVA applying Tukey's multiple comparisons test were performed using GraphPad Prism 7.0 software (GraphPad Software, California, USA) to estimate significant differences $(p<0.05)$ among samples with a confidence interval of $95 \%$.

\section{RESULTS}

The nutritional compositions of milks $A$ (pasture milk), B and C (conventional milks) were evaluated comparatively using results obtained from samples taken over various months. In order to determine if pasture milk has differences in composition compared to milk obtained from conventional systems, the CLA concentration and the $\omega 6 / \omega 3$ ratio, that are proven to have beneficial properties to human health, were analyzed.

The concentration of CLA present in the different milks (A, B and C) as well as its variation over 3 years (2018, 2019 and 2020) were analyzed and a graph was performed for easier comparison (Figure 1). The results demonstrated that the CLA concentration in the milk $\mathrm{A}$, the pasture milk, is always higher and presents a more constant profile throughout the sampling period. For milk $A$, the average is $10.5 \mathrm{mg} / 100 \mathrm{~g}$ of CLA, being $53.6 \%$ higher than that of milk B $(6.8$ $\mathrm{mg} / 100 \mathrm{~g})$ and $32.6 \%$ higher than that of milk C $(7.9 \mathrm{mg} / 100 \mathrm{~g})$. In comparison to milk $A$, milks $B$ and $C$ present a higher variation of the CLA concentration which is graphically visible (Figure 1).

The $\omega 6 / \omega 3$ ratio of the different milks and its variation were also analyzed over the same 3 years and the results are presented in a graph for easier analysis (Figure 2). It is graphically observed that the most constant profile regarding the $\omega 6 / \omega 3$ ratio belongs to milk $A$. Moreover, milk $A$ has lower ratio values in all the samples taken over the 3 years of analysis. The average $\omega 6 / \omega 3$ ratio from milk $A$ is 6.1 , being $42.2 \%$ lower than that of milk $B(10.5)$ and $41.3 \%$ lower than that of milk $C$ (10.4). Moreover, milks $B$ and $C$ present high variation through the period of analysis (Figure 2).

The results of the statistical analysis performed (Table 1) indicates that milk $A$ is statistically different from milk $B$ and $C$ both in the average CLA concentration and in the average $\omega 6 / \omega 3$ ratio, with milk $B$ and $\mathrm{C}$ do not indicate statistically significant differences between them.

\section{DISCUSSION OF THE RESULTS}

Milk is a drink of election in human diet. Nowadays, society is more concerned with health and, consequently, the demand for food with greater health benefits has increased (25).

CLA has been reported to have several advantages to human health (8-12). Since CLA cannot be synthesized by human metabolism it can only be obtained by consuming meat and/or dairy products (26). In this way, milk represents an important aliment for the obtention of CLA. O'Callaghan et al. (24) in a study to compare the effects of different feeding systems on milk quality and composition show that milk from pasture-feeding systems has a CLA concentration over 2-fold higher. Similar to that study, the present work shows that pasture milk not only has higher values of CLA concentration through the time of analyses, but also a more constant profile. 
Concentration of conjugated linoleic acid (CLA) over the sampling period from 2018, 2019 and 2020

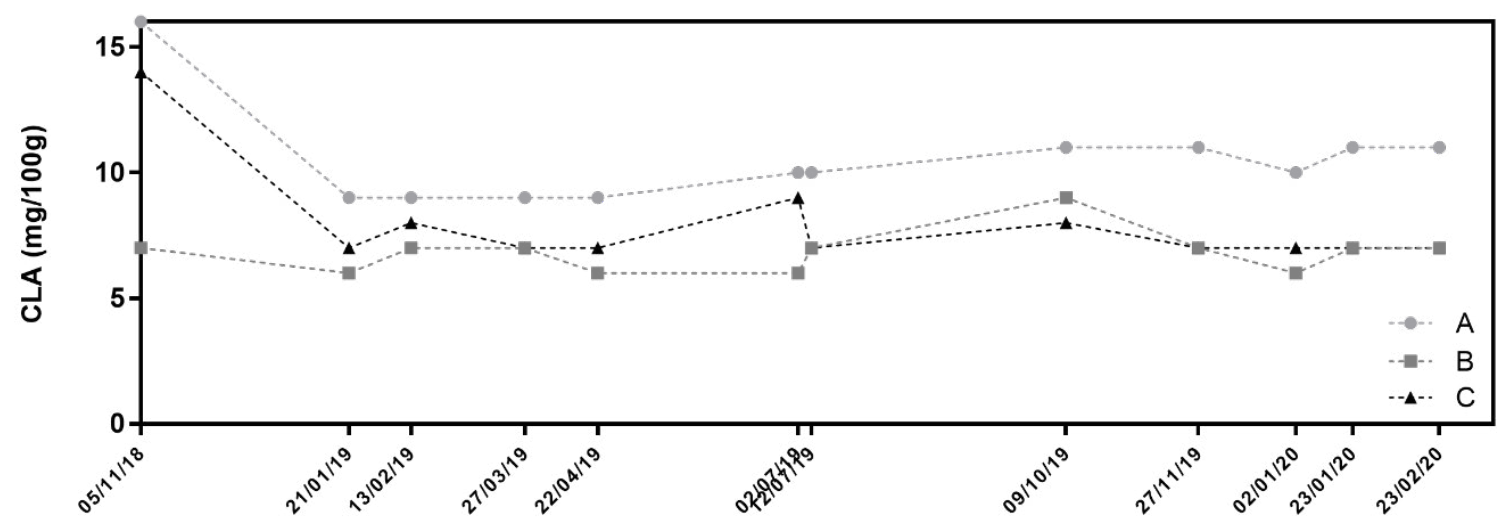

Time

A: Milk obtained through pasture-feeding system

$\mathrm{B}$ and $\mathrm{C}$ : Milk obtained through conventional system (intensive indoor)

\section{Figure 2}

Omega-6/omega-3 ratio (w6/w3) over the sampling period from 2018, 2019 and 2020

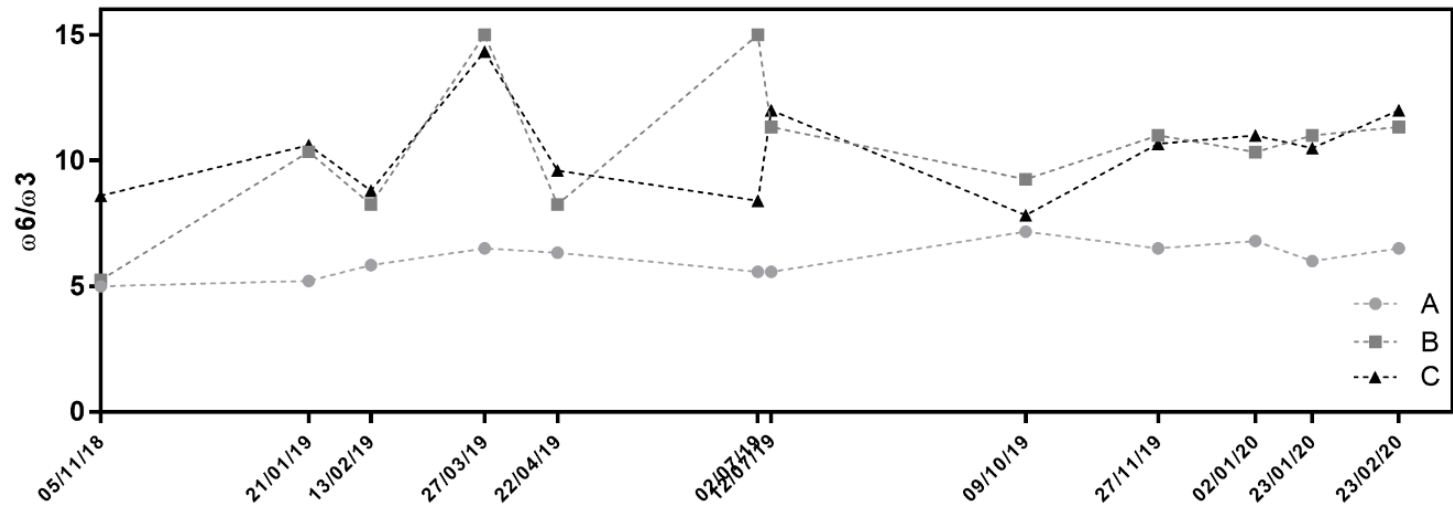

A: Milk obtained through pasture-feeding system

Time

$\mathrm{B}$ and C: Milk obtained through conventional system (intensive indoor)

Table 1

Conjugated linoleic acid (CLA) concentration and $\omega 6 / \omega 3$ ratio

\begin{tabular}{ccc} 
MILK & CLA (mg/100 g) & $\omega 6 / \omega 3$ \\
A & $10.5 \pm 1.8^{\mathrm{a}}$ & $6.1 \pm 0.6^{\mathrm{a}}$ \\
\hline B & $6.3 \pm 0.8^{\mathrm{b}}$ & $10.5 \pm 2.6^{\mathrm{b}}$ \\
\hline C & $7.9 \pm 1.9^{\mathrm{b}}$ & $10.4 \pm 1.8^{\mathrm{b}}$ \\
\hline
\end{tabular}

The values are represented as mean $\pm S D(n=12)$. Statistical analysis was performed using One-way ANOVA Tukey's multiple comparisons test. The same letters represent no significant differences at the $95 \%$ confidence level.

A: Milk obtained through pasture-feeding system

$\mathrm{B}$ and $\mathrm{C}$ : Milk obtained through conventional system (intensive indoor)

In recent years the $\omega 6 / \omega 3$ ratio in dietary products has received much attention. The optimum intake of $\omega 6 / \omega 3$ ratio is $4: 1$, however the current diet increases the $\omega 6$ to undesirable levels, coinciding with an increase of inflammatory-related diseases (27). Thus, it is extremally important to human health that people consume products with a recommended $\omega 6 / \omega 3$ ratio.

The results obtained in the present work show that pasture milk has a more proximal $\omega 6 / \omega 3$ ratio to the recommended and is less affected by the different factors that interfere with milk composition, since it presents a more constant profile. This result is supported by a study conducted by Benbrook et al. (28) where it is shown that pasture milk has less $\omega 6$, resulting in a $\omega 6 / \omega 3$ ratio more proximal to the recommended. O'Callaghan et al. (24) has similar results. Taking into account the benefits that CLA and a recommended $\omega 6 / \omega 3$ ratio have in human health and also the data analysis performed in this work it is possible to affirm that the pasture milk produced in Portugal has more nutritional interest than the milk obtained in the conventional systems Since at the time of this study there was only one milk produced through pasture-feeding system in Portugal, it was intended to compare this pasture milk with two brands of conventionally produced milk well established on the market. This study contributes to a global database that allows to verify that the only milk produced in Portugal through pasture-feeding system (at the date of the study) has a composition more favorable to human health with evidences that the fatty acids profile of milk could be improved by pasture-feeding systems. Moreover, pasture allows the cows to have a more natural environment and, consequently, the expression of their normal behavior (24). Thus, the milk obtained from pasture-feeding systems is considered more natural since it increases the welfare of the animal and the protection of the environment. 


\section{CONCLUSIONS}

This study allows the composition of the effect of two feeding systems in the lipidic profile, specifically, on the CLA concentration and the w6/ $\omega 3$ ratio over 3 years of sampling. In conclusion, the pasture-feeding system has been shown to produce milk with a composition that seems to have more health benefits and with a more constant composition over time, when compared with conventional-feeding systems. The pasture milk has an increased CLA concentration and a $\omega 6 / \omega 3$ ratio more proximal to the recommended. Thus, this study indicates the possibility of the fatty acids profiling of milk being improved by pasture feeding systems.

\section{DECLARATION OF INTERESTS}

The authors of the University of Minho are consultants to the company Bel Portugal, and they maintain all their scientific suitability.

\section{REFERENCES}

1. Kubicová L', Predanocyová K, Kádeková Z. The importance of milk and dairy products consumption as a part of rational nutrition. Potravin Slovak J Food Sci. 2019;13(1):234-43.

2. Organization F and A. Gateway to dairy production and products [Internet]. Dairy animals. 2017 [cited 2020 Mar 25]. Available from: http://www.fao.org/dairy-productionproducts/production/dairy-animals/en/.

3. Foroutan A, Guo AC, Vazquez-Fresno R, Lipfert M, Zhang L, Zheng J, et al. Chemical Composition of Commercial Cow's Milk. J Agric Food Chem. 2019 May 1;67(17):4897-914.

4. Walter L, Finch S, Cullen B, Fry R, Logan A, Leury BJ. The effect of physiological state, milk production traits and environmental conditions on milk fat globule size in cow's milk. J Dairy Res. 2019;86(4):454-60.

5. Pereira PC. Milk nutritional composition and its role in human health. Vol. 30, Nutrition. Elsevier Inc.; 2014. p. 619-27.

6. Lindmark Månsson H. Fatty acids in bovine milk fat. Food Nutr Res. 2008;52(10):1-3.

7. Jensen RG. The composition of bovine milk lipids: January 1995 to December 2000. Vol. 85, Journal of Dairy Science. American Dairy Science Association; 2002 p. 295-350.

8. Kathuria D, Gautam S, Sharma S, Sharma K. Animal based bioactives for health and wellness. Food Nutr J. 2019;4(203).

9. Paszczyk B, Polak-Śliwińska M, Łuczyńska J. Fatty acids profile, trans isomers, and lipid quality indices in smoked and unsmoked cheeses and cheese-Like Products. Int J Environ Res Public Health. 2019 Dec 20;17(1):71.

10. O'Reilly ME, Lenighan YM, Dillon E, Kajani S, Curley S, Bruen R, et al. Conjugated linoleic acid and alpha linolenic acid improve cholesterol homeostasis in obesity by modulating distinct hepatic protein pathways. Mol Nutr Food Res. 2020 Apr 1;64(7):1900599.

11. Kelsey JA, Corl BA, Collier RJ, Bauman DE. The effect of breed, parity, and stage of lactation on conjugated linoleic acid (CLA) in milk fat from dairy cows. J Dairy Sci. 2003 Aug 1;86(8):2588-97.

12. Marín MP, Meléndez PG, Aranda P, Ríos C. Conjugated linoleic acid content and fatty acids profile of milk from grazing dairy cows in southern Chile fed varying amounts of concentrate. J Appl Anim Res. 2018;46(1):150-4.

13. Murru E, Carta G, Cordeddu L, Melis M, Desogus E, Ansar H, et al. Dietary Conjugated Linoleic Acid-Enriched Cheeses Influence the Levels of Circulating n-3 Highly Unsaturated Fatty Acids in Humans. Int J Mol Sci. 2018;19(6):1730.

14. Simopoulos AP. Evolutionary aspects of diet: The omega-6/omega-3 ratio and the brain. Mol Neurobiol. 2011;44(2):203-15.

15. Simopoulos AP. The importance of the ratio of omega-6/omega-3 essential fatty acids. Biomed Pharmacother. 2002;56(8):365-79.

16. Kala R, Samková E, Koubová J, Hasoňová L, Kvác M, Pelikánová T, et al. Nutritionally desirable fatty acids including CLA of cow's milk fat explained by animal and feed factors. Acta Univ Agric Silvic Mendelianae Brun. 2018 Feb 28;66(1):69-76.
17. Roessler R, Mpouam SE, Schlecht E. Genetic and nongenetic factors affecting on-farm performance of peri-urban dairy cattle in west Africa. J Dairy Sci. 2019 Mar 1;102(3):2353-64.

18. Bär C, Sutter M, Kopp C, Neuhaus P, Portmann R, Egger L, et al. Impact of herbage proportion, animal breed, lactation stage and season on the fatty acid and protein composition of milk. Int Dairy J. 2020 Jun 18;104785.

19. Stergiadis S, Leifert C, Seal CJ, Eyre MD, Steinshamn H, Butler G. Improving the fatty acid profile of winter milk from housed cows with contrasting feeding regimes by oilseed supplementation. Food Chem. 2014 Dec 1;164:293-300.

20. van Valenberg HJF, Hettinga KA, Dijkstra J, Bovenhuis H, Feskens EJM. Concentrations of $n-3$ and $n-6$ fatty acids in Dutch bovine milk fat and their contribution to human dietary intake. J Dairy Sci. 2013;96(7):4173-81.

21. Butler G, Stergiadis S, Seal C, Eyre M, Leifert C. Fat composition of organic and conventional retail milk in northeast England. J Dairy Sci. 2011 Jan;94(1):24-36.

22. Mekuriaw S, Tsunekawa A, Ichinohe T, Tegegne F, Haregeweyn N, Kobayashi N, et al. Effect of feeding improved grass hays and eragrostis tef straw silage on milk yield, nitrogen utilization, and methane emission of lactating Fogera dairy cows in Ethiopia. Animals. 2020 Jun 11;10(6):1021.

23. Wilkinson JM, Lee MRF, Rivero MJ, Chamberlain AT. Some challenges and opportunities for grazing dairy cows on temperate pastures. Grass Forage Sci. 2020 Mar 2;75(1):1-17.

24. O'Callaghan TF, Hennessy D, McAuliffe S, Kilcawley KN, O'Donovan M, Dillon P, et al. Effect of pasture versus indoor feeding systems on raw milk composition and quality over an entire lactation. J Dairy Sci. 2016 Dec 1;99(12):9424-40.

25. Rose D, Heller MC, Roberto CA. Position of the Society for Nutrition Education and Behavior: The Importance of Including Environmental Sustainability in Dietary Guidance. J Nutr Educ Behav. 2019 Jan 1;51(1):3-15.e1.

26. Virsangbhai CK, Goyal A, Tanwar B, Sihag MK. Potential Health Benefits of Conjugated Linoleic Acid: An Important Functional Dairy Ingredient. Eur J Nutr Food Saf. 2019;11(4):200-13.

27. Patterson E, Wal R, Fitzgerald G, Ross R, Stanton C. Health implications of high dietary omega-6 polyunsaturated fatty acids. J Nutr Metab. 2012;2012:539426.

28. Benbrook CM, Butler G, Latif MA, Leifert C, Davis DR. Organic production enhances milk nutritional quality by shifting fatty acid composition: A United Stateswide, 18-month study. PLoS One. 2013 Dec 9;8(12):e82429. 